\title{
Types of hardware and software in use and problems associated with their use in secondary agricultural education programs in West Virginia
}

\author{
David T. Aberegg \\ West Virginia University
}

Follow this and additional works at: https://researchrepository.wvu.edu/etd

\section{Recommended Citation}

Aberegg, David T., "Types of hardware and software in use and problems associated with their use in secondary agricultural education programs in West Virginia" (2004). Graduate Theses, Dissertations, and Problem Reports. 1957.

https://researchrepository.wvu.edu/etd/1957

This Thesis is protected by copyright and/or related rights. It has been brought to you by the The Research Repository @ WVU with permission from the rights-holder(s). You are free to use this Thesis in any way that is permitted by the copyright and related rights legislation that applies to your use. For other uses you must obtain permission from the rights-holder(s) directly, unless additional rights are indicated by a Creative Commons license in the record and/ or on the work itself. This Thesis has been accepted for inclusion in WVU Graduate Theses, Dissertations, and Problem Reports collection by an authorized administrator of The Research Repository @ WVU. For more information, please contact researchrepository@mail.wvu.edu. 
Types of Hardware and Software in Use and Problems Associated with Their Use in Secondary Agricultural Education Programs in West Virginia.

\title{
David T. Aberegg
}

Thesis submitted to the Davis College of Agriculture, Forestry, and Consumer Sciences at West Virginia University in partial fulfillment of the requirements for the degree of

\author{
Master of Science \\ in \\ Agricultural and Environmental Education
}

Harry N. Boone, Jr., Ph.D., Chair Stacy A. Gartin, Ph.D.

Deborah A. Boone, Ph.D.

Division of Resource Management

Morgantown, West Virginia 2004

Keywords: Microcomputers, Agriculture Education 


\begin{abstract}
Types of Hardware and Software in Use and Problems Associated with Their Use in Secondary Agricultural Education Programs in West Virginia.
\end{abstract}

\title{
David T. Aberegg
}

Microcomputers have become a vital tool in business, industry, and education. The level and the amount of education that students in West Virginia receive in secondary agricultural classes on microcomputers can affect their ability to compete for jobs and in college curriculums. For agriculture programs to produce quality graduates ready to meet the demands of today's work place, they must have up-to-date microcomputing hardware and software. This study examined the accessibility to computers by teachers of agriculture education in West Virginia. A survey was sent to 74 agriculture education departments in West Virginia. The results showed that most departments are using computers for word processing applications, gradebooks, and class lists. Most departments did not commonly use spreadsheets or databases. Online research was the most common use of telecommunications. Windows ${ }^{\circledR}$ 95-97 was the most common operating system. Most departmental computers have 3.5-inch floppy drives and CD ROMS. Most departments have two to five computers. 


\section{ACKNOWLEDGEMENTS}

I would like to thank the people that made this possible; Harry N. Boone, Jr., Ph.D., Stacy A. Gartin, Ph.D., Deborah A. Boone, Ph.D., and Layle D. Lawrence Ph.D. I would also like to thank my family and the many others that have helped me along the way. 


\section{TABLE OF CONTENTS}

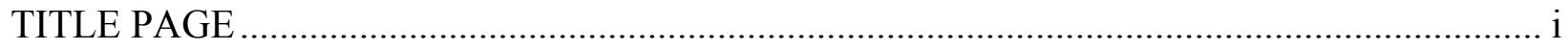

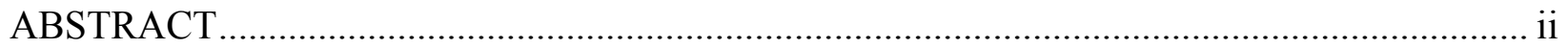

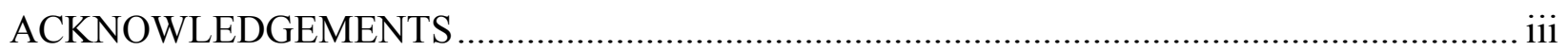

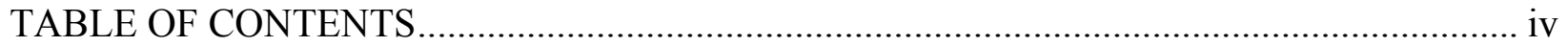

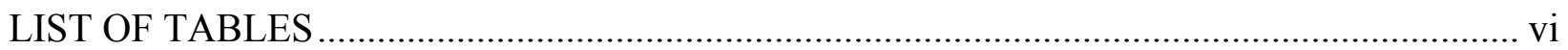

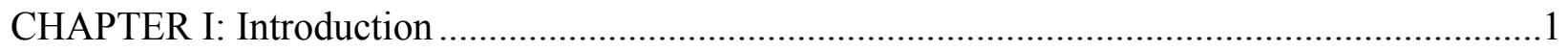

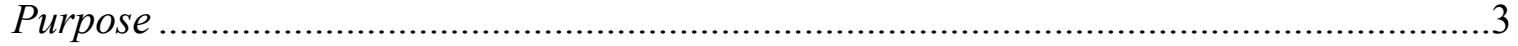

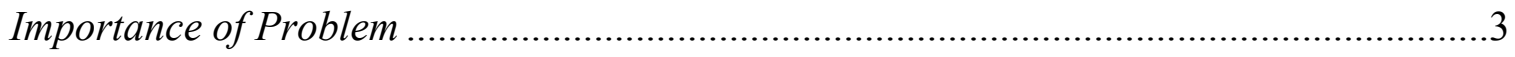

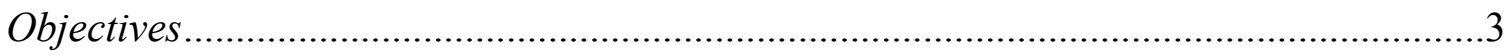

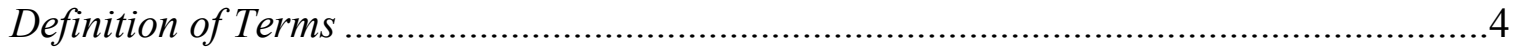

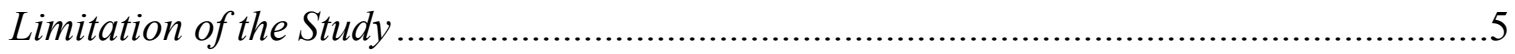

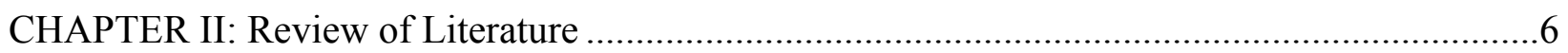

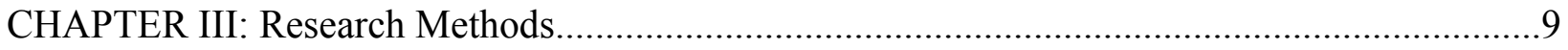

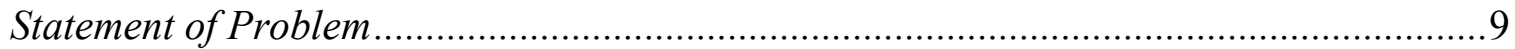

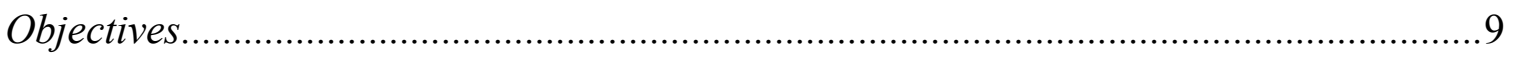

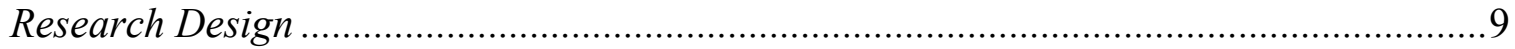

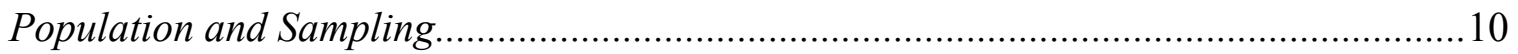

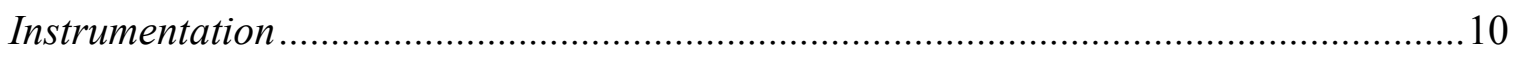

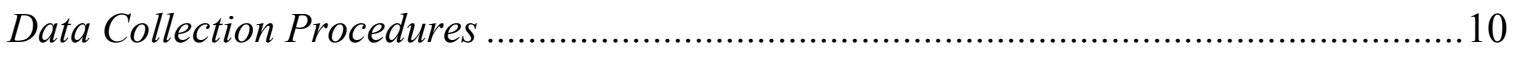

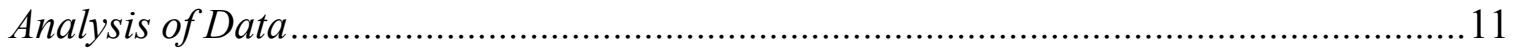

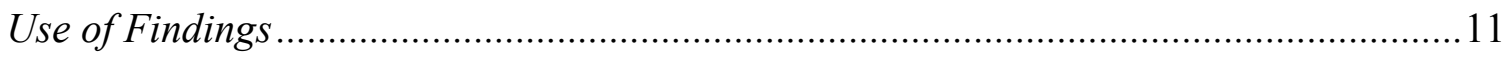

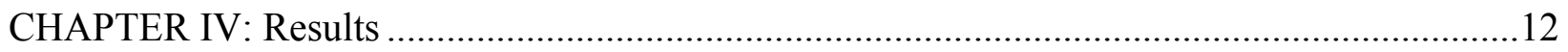

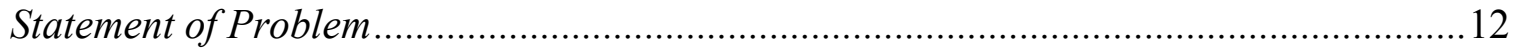

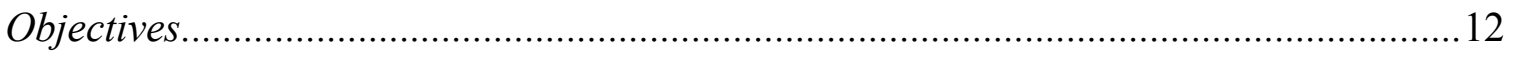

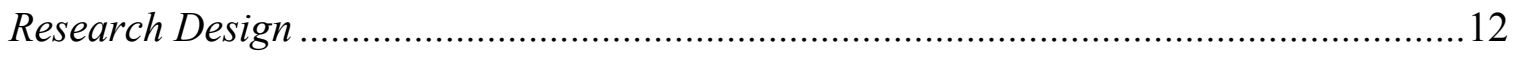

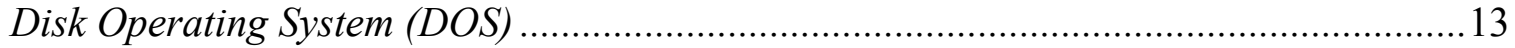

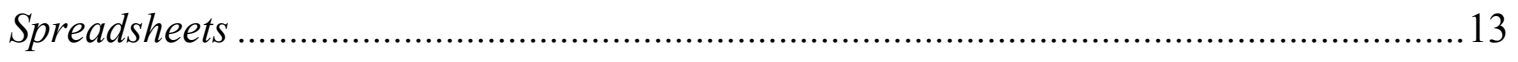

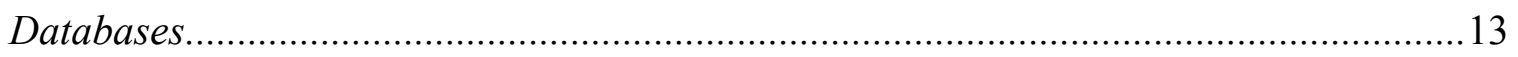

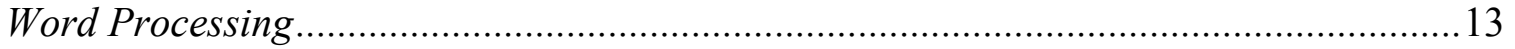

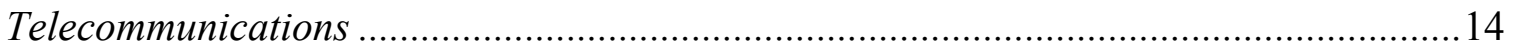


Graphics

Statistical Programs

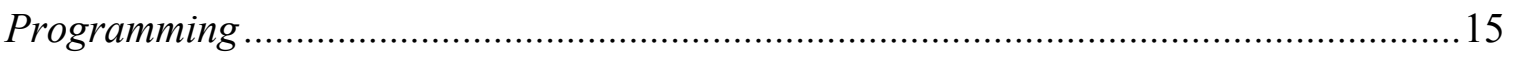

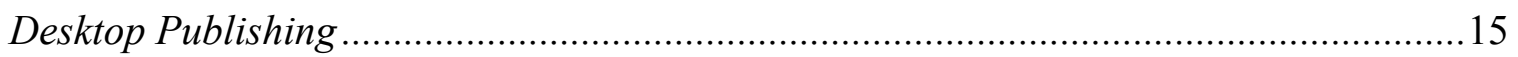

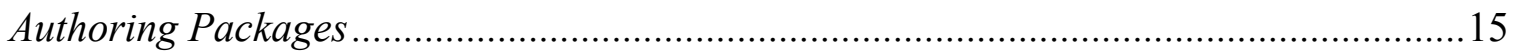

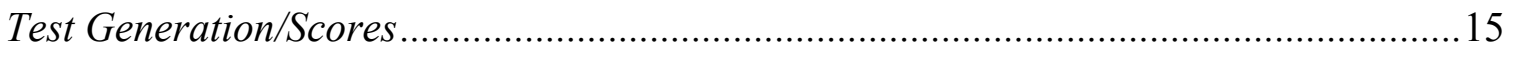

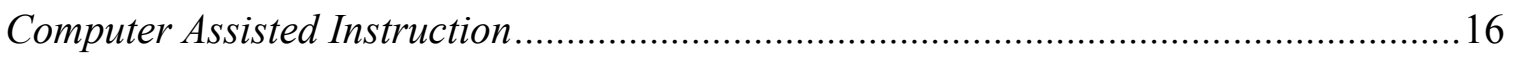

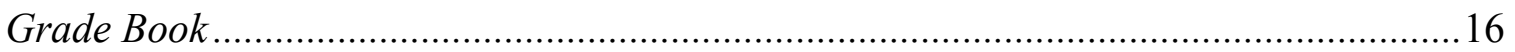

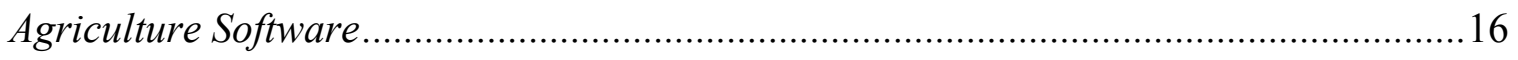

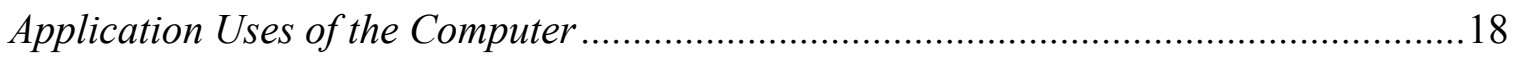

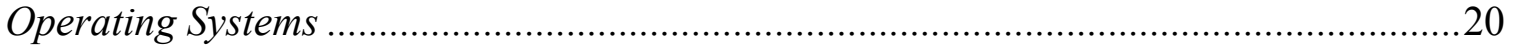

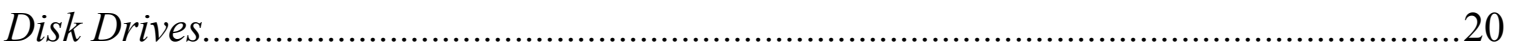

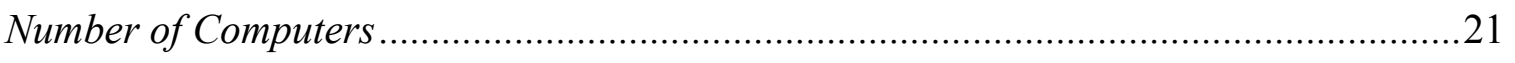

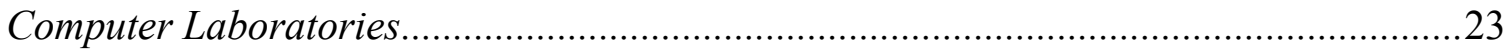

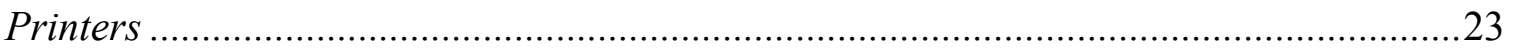

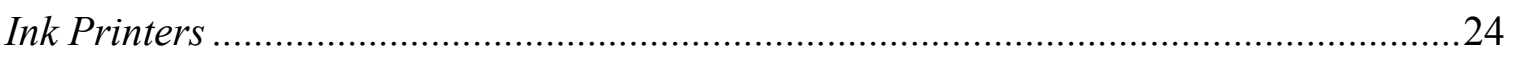

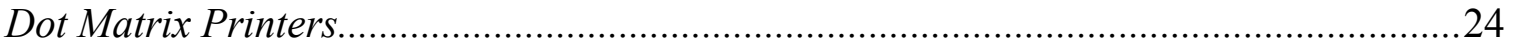

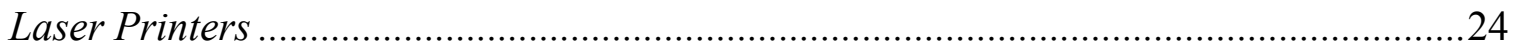

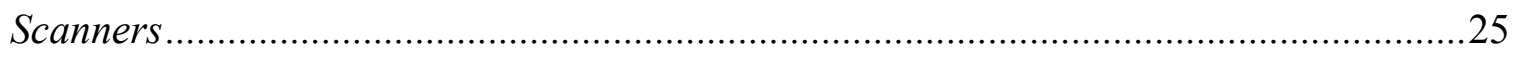

Liquid Crystal Display (LCD) Projectors..............................................................25

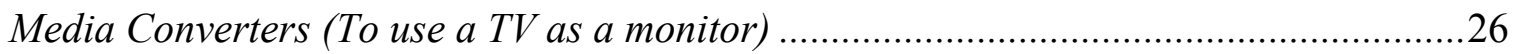

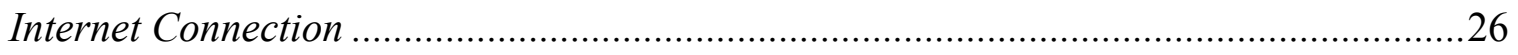

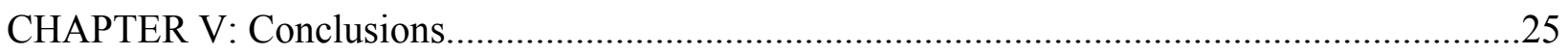

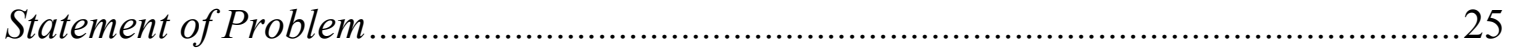

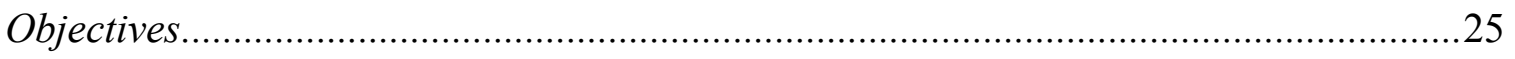

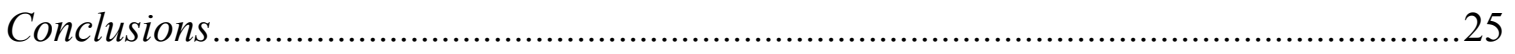

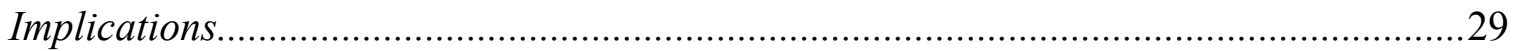

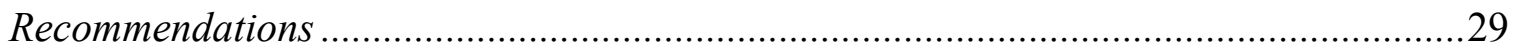

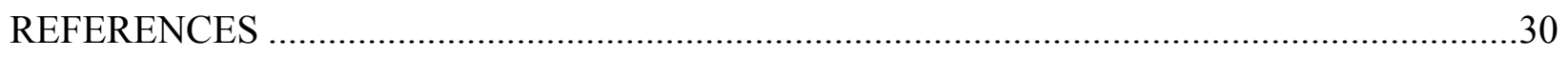

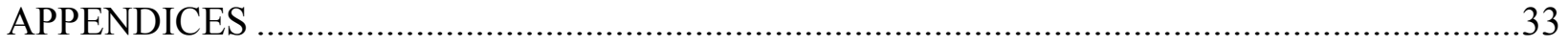

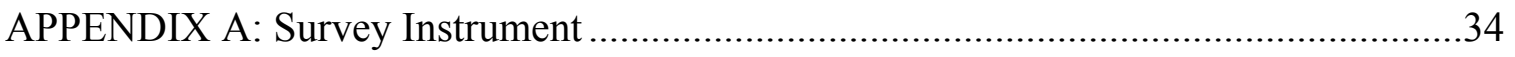


APPENDIX B: Letter to Participating WV Agriculture Teachers .................................40

APPENDIX C: Follow Up Letter to WV Agriculture Teachers....................................42

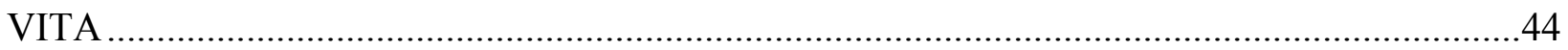




\section{LIST OF TABLES}

Tables Title Page

Table $1 \quad$ Software Usage Reported by Agriculture Education Teachers ...........................17

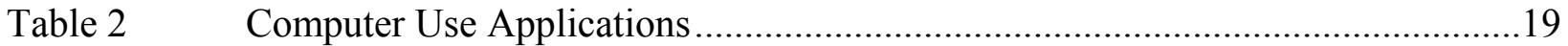

Table 3 Availability of Disk Drives ......................................................................21

Table $4 \quad$ Number of Computers in Each Department Use of Microcomputer Labs ...........22

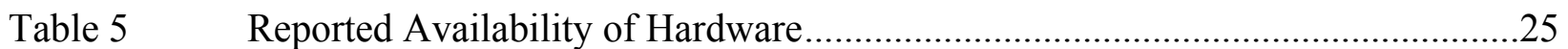




\section{CHAPTER I}

Introduction

Microcomputers are used in nearly every phase of the agricultural industry. To properly equip high school graduates to work in agriculture, teachers began to incorporate microcomputers and related technologies into the high school agriculture curriculum in the mid 1980s. This concept continues today at both the college and secondary education levels, leading to questions as to the types of technology in the classroom as well as how it has been used (U.S. Department of Education, 2000). Important microcomputer-related technologies available today include telecommunications hardware, printers, plotters, remote sensing and control devices, optical scanners, video-disk equipment, and many hardware devices as well as the associated software to operate the systems (Camp as cited by Camp \& Sutphin, 1991). According to Hill and Hannafin (2001) technology capabilities hold promise for teaching and learning. Schools and classrooms need to become resource intensive (Reigeluth as cited by Hill \& Hannafin, 2001) where digital resources can be readily generated and accessed per specific goals of teachers or students. Camp and Sutphin (1991) found that a majority of experts consisting of agriculture education teachers, teacher educators, state supervisors and representatives from computer intensive agriculture industries felt that too few computing and computer-related curriculum materials and guidelines were available for agriculture teachers. Bowen, Mincemoyer, and Parmley (1983) stated that the use of microcomputers by agricultural education programs appeared to be increasing. This is further supported by U.S. Department of Education (2000), who stated that computers in schools have increased to one computer for every six students. Agriculture departments were more likely to have computers if the principal and school board of education supported the use of computers (Miller \& Kotrlik 1987). 
According to Miller and Kotrlik (1987) computers were used more for instructional management than they were for tutorial or direct instructional purposes. Computers (Zidon \& Luft, 1986) were primarily used as decision aids and tutorial programs in such units as farm business, supervised occupational experience programs (SOE), animal nutrition, FFA leadership, and crop science, as well as for non-instructional uses such as word processing, correspondence, entertainment and test generation. According to Odell (1994), West Virginia teachers reported minimal knowledge in spreadsheets, databases, computer assisted instruction, test generation and scoring, telecommunications, grade books, graphics, and programming. The U.S. Department of Education (2000) reported that the use of many of these applications had greatly increased. The U.S. Department of Education (2000) reported a number of new applications not listed by Odell (1994), Zidon and Luft (1986), or Miller and Kotrlik (1987). The differences were most likely due to new software availability.

West Virginia agriculture teachers and teacher education institutions must recognize the need for continued in-service programs to keep pace with the ever-changing technology (Odell, 1994). With computers and related technology rapidly changing and being used in the agriculture programs, it is important to know how they are being used and what factors contribute to and against increased use of technology in the classroom. As the use of microcomputers in secondary school agriculture programs grows, it is important to understand the stages in this growth process so that appropriate strategies can be planned for future microcomputer utilization (Odell, 1994).

Davis (1997) and Andelt, Barrett, and Bosshamer (1997) found similar results with their studies in that employers rated computer skills as either important or very important. This shows the need for students to become skilled in computer usage. Radhakrishna and Bruning (as cited by Johnson, Ferguson, \& Lester, 2002) state that Pennsylvania State University graduates rated 
computer skills as slightly more important to job success than technical agriculture skills. This need for computer skills by employers shows there is a need for students to have computers skills when entering the work force. Odell in 1994 found that microcomputer use was limited in West Virginia secondary agricultural education programs. This study will look at how the use of microcomputers has increased and evolved during the past seven years and if the use has kept pace with the rapid change in microcomputers.

\section{Purpose}

The advent of the computer age has led to more affordable computers and related hardware and software, making them more reasonable to purchase and use. However, little is known about the current status of their use in the West Virginia secondary agriculture classroom. The latest study of this type in West Virginia was published in 1994 and much has changed with computers since that time. The changes in computers and related technology have created the need to know what is being taught and what types of computers and related equipment teachers have available as well as what is limiting them from using these tools. This study was designed to determine what types of computer equipment exists in West Virginia's agricultural education programs, how the equipment was being utilized for the instructional program, and what factors limited the use of the equipment. The study results will provide information to state supervisors and teacher educators that might be useful in planning in-service strategies to maintain competencies of teachers in the use of computers.

\section{Importance of Problem}

Microcomputers have become a vital tool in businesses, industry and education. For this reason they can be a valuable asset when computers are taught to students in secondary agricultural classes. The level and the amount of education that students in West Virginia receive 
in secondary agricultural classes on microcomputers can affect their ability to compete for jobs and in college curriculums. For West Virginia secondary school agriculture programs to produce quality graduates ready to meet the demands of today's work place, they must have up-to-date microcomputing hardware and software. The U.S. Department of Education (2000) reports that the presence of computers and the Internet has greatly increased but much of the computer equipment in schools is from earlier generations and limited in capabilities. It is only through active and continued use that students can develop skills and see the value and benefits of microcomputer utilization in agriculture (Odell, 1994).

\section{Objectives}

The specific objectives of this study were:

1. Identify the types of microcomputer hardware and software available and used by secondary agricultural education programs.

2. Identify problems associated with the use of microcomputers in the classroom.

3. Determine the types of microcomputers activities used by secondary agricultural education programs.

\section{Definition of Terms}

Activities: How the microcomputer is being used in the classroom and in the facilitation of class proceedings.

Authoring Packages: Software that can be used to generate individualized instruction modules.

Competency level: Ability of the teacher to convey and use the available hardware and software effectively. 
Hardware: Microcomputers, laptops, and associated digital equipment for teaching, such as computer laboratories, computers in the classroom, and availability of the equipment with four basic functions: Central Processing Unit (CPU), input, output and memory

Microcomputer: A small computer based on a microprocessor, a personal computer.

Software: The programs and usable operating systems for the hardware being used.

Related Technology: Equipment such as upgraded computers, printers, scanners, disk drives, RGB converters, and speakers.

Telecommunications: Equipment such as modems and connecting devices as well as E-mail programs and Internet browsing programs

\section{Limitations of the Study}

The study was limited to agricultural education programs in the State of West Virginia during spring semester 2002. 


\section{CHAPTER II}

\section{Review of Literature}

Microcomputers have become an integral part of modern society (Raven \& Welton, 1988). In 1986, Bowen, Mincemoyer, and Parmley reported that the predominate computers in use were Tandy Radio Shack models I and III, Apple II and III, Commodore PET, and IBM. Many had telephone hookups and most had a printer, which was the main extent of digital equipment at the time. Bowen et al., (1986) also noted that the use of microcomputers by agricultural education programs appeared to be increasing.

Most agriculture departments in North Dakota have computers or access to them (Zidon \& Luft, 1986). Zidon and Luft also reported that teachers tend to use computers when software is available. Many of the uses of the computer were for administrative purposes such as word processing and test generation.

Camp and Sutphin (1988) reported that many experts felt there were too few computer related curriculums available for agriculture teachers. They noted that hardware and software technologies change so rapidly that standards for curriculums would need updating too often to make a standard feasible.

Raven and Welton (1988) found that agriculture teachers in Kansas perceived the lack of time to learn more about computers as the major factor inhibiting computer usage. The lack of funding for hardware and software was another factor limiting computer usage. Raven and Welton (1988) went on to suggest that due to the notable instructional value computers can have in the classroom, teacher competencies in computer usage should be required.

Rohrbach and Stewart (1986) found that students learned as well with computer-assisted instruction as they did with lecture based instruction. However, the research showed that 
different factors could vary these results. The study did not look at how the computer could be used as a tool in conjunction with other instruction tools in the classroom setting.

Birkenholtz, Stewart, McCaskey, Ogle, and Linhardt (1989) found that microcomputers could be utilized effectively in agriculture using tutorial, drill and practice, and simulation teaching. Birkenholtz et al., (1989) also noted that microcomputers could be used to replace portions of traditional instruction for secondary agriculture students.

The use of microcomputers in education and in agriculture has not only come of age but changes almost daily. Miller and Foster (1986) addressed this increased need for microcomputer competency in vocational agriculture. They asserted that teacher education programs must assume an active role in preparing teachers to use all forms of computer instruction.

On the most basic level, teachers may be more likely to integrate computers and the Internet into classroom instruction if they have access to adequate equipment and connections. Research indicates that the number of computers in America's classrooms and schools has grown substantially in recent years. (U.S. Department of Education, 2000.)

Odell (1994) reported that West Virginia secondary agriculture teachers have access to at least one microcomputer. The one microcomputer was used primarily for the development of material in support of instruction but very little in the area of instruction itself. Current research indicates that computers are more prominent in the United States. Glennan and Melmed found in1983 there was an average of one computer for every 125 students (as cited by U.S. Department of Education, 2000). In 1998 Rowand found the average had increased to one computer for every six students (as cited by U.S. Department of Education, 2000). Odell (1994) reported that teachers considered a lack of time, hardware, software, and training as barriers to increased use of the microcomputer. Levin et al. (as cited by U.S. Department of Education, 
2000) stated that as availability has grown, so has the number of students and teachers using computers and the frequency with which they use them. U.S. Department of Education (2000) also reported that even though there was technology in the classrooms, much of it is outdated. Odell reported in 1994 that microcomputer technology had changed rapidly over the past ten years. Current research shows that change has not slowed. Odell (1994) stated that keeping pace with change has been a problem for the past three decades and for West Virginia agriculture students to be prepared for today's work place, they need up-to-date hardware and software. 


\section{CHAPTER III}

Research Methods

\section{Statement of Problem}

This study was designed to determine what types of computer equipment exist in West Virginia's agricultural education programs, how the equipment was being utilized for the instructional program, and what factors limited the use of the equipment. The study results will provide information to state supervisors and teacher educators that might be useful in planning in-service strategies to maintain competencies of teachers in the use of computers.

\section{Objectives}

The specific objectives of this study were:

1. Identify the types of microcomputer hardware and software available and used by secondary agricultural education programs.

2. Identify problems associated with the use of microcomputers in the classroom.

3. Determine the types of microcomputers activities used by secondary agricultural education programs.

\section{Research Design}

A descriptive survey design was used to gather information for this study. Patten (2000) states "The purpose of surveys is to descriptive the attitudes, beliefs and behavior of a population.” (p. 9). A survey was used to collect data to assess the status of computers in West Virginia secondary agriculture programs, explore what problems exist with their use, and determine the ways they are being used. 


\section{Population and Sampling}

The target population was all agricultural education programs in West Virginia. A list of programs was obtained from the state director of agriculture education and West Virginia University's Agricultural education faculty. The accessible population was 74 agricultural education programs listed in the directory of agricultural teachers for the school year 2001-2002. There were 47 agriculture education programs that responded.

Using a census of programs in West Virginia eliminated sampling error. Using official lists provided by the State Department of Education and West Virginia University eliminated frame error.

\section{Instrumentation}

The survey used was adapted from a previous study on microcomputer utilization in West Virginia secondary school agriculture programs by Odell (1994). The survey contained Likerttype items to determine the time used in various types of computer activities and the frequency of using various computer applications. Participants were requested to indicate the equipment and accessories available to them with regards to Internet access, hardware and access to computers. Validity of the revised survey was established by a panel of experts consisting of faculty in Agricultural and Environmental Education at West Virginia University.

\section{Data Collection Procedures}

The surveys, along with a cover letter, were handed out to teachers as they arrived at the West Virginia FFA state convention in early July 2002. A cover letter and a survey were sent to programs that did not have a teacher at the state convention one week following the convention. Multi-teacher programs were asked to have only one teacher respond to the survey. The cover letter explained the purpose and background information for the survey. It also provided basic 
directions to complete the survey. The cover letter also established a return deadline. After the deadline for the surveys had elapsed a second follow-up survey and cover letter were sent to those agricultural education departments that had not yet returned surveys. The second cover letter was similar to the first one with an explanation that the first survey had not been received. This became the basis of early and late respondents for statistical analysis of non-response bias.

Surveys, handed out at the convention, were collected in a box each evening at the final assembly and at breakfast to allow time for teachers to complete the survey and to allow for confidentiality.

Surveys were sorted as late and early respondents. To determine non-response bias early and late respondents were compared. Smith and Miller (1983) have found that late respondents are similar to non-respondents.

Analysis of Data

Responses were entered into a Microsoft Excel worksheet for inspection and ease of data analysis. The data were transferred to the Statistical Package for the Social Sciences for analysis. Appropriate descriptive statistics were used including frequencies, means, and standard deviation were used.

Use of Findings

Findings will be used to further define the use of computers in secondary agriculture education. State Agriculture Education programs and colleges should be better prepared to assist teachers in the uses of computers. 


\section{CHAPTER IV}

Results

\section{Statement of Problem}

This study was designed to determine types of computer equipment exist in West Virginia's agricultural education programs, how the equipment was being utilized for the instructional program, and what factors limited the use of the equipment. The study results will provide information to state supervisors and teacher educators that might be useful in planning in-service strategies to maintain competencies of teachers in the use of computers.

\section{Objectives}

The specific objectives of this study were:

1. Identify the types of microcomputer hardware and software available and used by secondary agricultural education programs.

2. Identify problems associated with the use of microcomputers in the classroom.

3. Determine the types of microcomputer activities used by secondary agricultural education programs.

\section{Population}

The target population consisted of 74 high school agricultural education programs in West Virginia. Forty-seven agricultural education teachers (63.5\%), representing 47 departments responded to the survey. Responses from early and late respondents were compared to determine if non-response error existed in the data. Because significant differences were found between early and late respondents, generalizations were limited to those individuals who responded to the survey. Respondents, according to West Virginia University's Institutional 
Review Board policies, were instructed they did not have to respond to every question. As a result, not all of the questions have the same number of responses.

Disk Operating System (DOS)

Respondents were asked to report the frequency they used the DOS operating system. They were given none, daily, weekly, and yearly as categories for their responses. The largest response to the use of DOS was none with 18 respondents (39.1\%). Another 11 respondents (23.9\%) reported DOS was used on a yearly basis. The remaining 15 respondents $(32.7 \%)$ reported monthly, weekly, or daily use of DOS with seven respondents (15.2\%) reporting daily use of DOS. Spreadsheets

Respondents were asked to report the frequency they used electronic spreadsheets. Of the 44 respondents, ten $(21.7 \%)$ reported using spreadsheets daily. Eight respondents $(17.4 \%)$ reported weekly use of spreadsheets and six respondents (13.0\%) reported no use of spreadsheets at all.

\section{Databases}

Respondents were asked to report the frequency they used database software. Eleven respondents $(21.7 \%)$ reported using database software on a yearly basis, 12 respondents $(26.1 \%)$ reported monthly use of database software, seven respondents (15.2\%) reported weekly use, seven respondents (15.2\%) reported daily use, and eight respondents reported no use (17.4\%) of database software.

\section{Word Processing}

Respondents were asked to report the frequency they used word processing software. Thirty-one respondents $(67.4 \%)$ reported daily use of word processing software, whereas, 11 
respondents $(23.9 \%)$ reported using word processing weekly. Only one respondent $(2.2 \%)$ reported using word processing on a monthly basis and one respondent $(2.2 \%)$ reported yearly use of the software. None of the respondents reported no use of word processing software.

\section{Telecommunications}

Respondents were asked to report the frequency they used telecommunications software. The majority of respondents $(50.0 \%)$ indicated daily use of telecommunications software. Of the 44 respondents, nine (19.6\%) used telecommunications software weekly and six (13.0\%) used telecommunication software monthly. Four respondents $(8.7 \%)$ reported no use of telecommunications software and two respondents (4.3\%) reported using telecommunications on a yearly basis.

\section{Graphics}

Respondents were asked to report the frequency they used graphics software. The most frequent response was monthly with 16 respondents $(34.8 \%)$. Weekly use of graphic software was reported by 12 respondents (26.1\%). Another ten respondents $(21.7 \%)$ reported yearly use of graphics software. Four respondents reported no use $(8.7 \%)$ of graphics software and two respondents $(4.3 \%)$ reported daily use of graphics software.

\section{Statistical Programs}

Respondents were asked to report the frequency they used statistical programs. Half of the respondents $(n=23,50.0 \%)$ indicated no use of statistical programs. Ten respondents $(21.7 \%)$ reporting monthly use and seven respondents $(15.2 \%)$ reported yearly use of statistical software. Three respondents $(6.5 \%)$ reported weekly and one respondent $(2.2 \%)$ reported daily use of statistical programs. 


\section{Programming}

Respondents were asked to report the frequency they used computer programming. The majority of the respondents $(n=27,58.7 \%)$ indicated no use of computer programming. Nine respondents $(19.6 \%)$ reported monthly use, six respondents $(13.0 \%)$ reported yearly use, two respondents (4.3\%) reported weekly use, and none of the respondents reported daily use of computer programming.

\section{Desktop Publishing}

Respondents were asked to report the frequency that they used desktop publishing. None was the most common response to use of desktop publishing with 12 respondents $(26.1 \%)$. Monthly, was the next most common response with 11 respondents $(23.6 \%)$. The yearly use of desktop publishing was reported by ten respondents (21.7\%). Eight respondents (17.4\%) reported weekly use and three (6.5\%) respondents reported daily use of desktop publishing software.

\section{Authoring Packages}

Respondents were asked to report the frequency they used authoring packages. The majority of the respondents $(n=32,69.6 \%)$ did not use authoring packages. Monthly use of authoring packages was reported by six respondents (13.0\%). Five respondents $(10.9 \%)$ reported yearly use of authoring packages. There were no responses reported for either weekly or daily use.

\section{Test Generation /Scores}

Respondents were asked to report the frequency they used programs for test generation or scores. Nineteen respondents $(41.3 \%)$ reported using this category of software weekly. Ten respondents $(21.7 \%)$ reported no use of the software, eight respondents $(17.4 \%)$ reported 
monthly use, six respondents (13.0\%) reported daily use, and one respondent $(2.2 \%)$ reported yearly use of test generation software.

\section{Computer Assisted Instruction}

Respondents were asked to report the frequency they used computer-assisted instruction. The most frequent use of computer assisted instruction software $(n=14,30.4 \%)$ was on a monthly basis. Ten respondents $(21.7 \%)$ reported using the software weekly. There were nine respondents (19.6\%) reporting no use of computer-assisted instruction. Six respondents (13.0\%) reported only yearly use and five respondents (10.9\%) reported daily use of computer assisted instruction software.

Grade Book

Respondents were asked to report the frequency that they used computer software for a grade book. The majority of respondents $(n=24,52.2 \%)$ reported daily use. This was followed by 11 respondents $(23.9 \%)$ reporting no use. Weekly use of grade book software was reported by six respondents (13.0\%). Only two respondents (4.3\%) reported monthly use and one respondent $(2.2 \%)$ reported daily use of a computer grade book.

Agriculture Software

Respondents were asked to report the frequency they used agricultural software. Eighteen respondents (39.1\%) reported using agriculture software monthly. Ten respondents $(21.7 \%)$ reported using the software either weekly or daily. Three respondents $(6.5 \%)$ reported yearly use and three respondents $(6.5 \%)$ reported no use of agricultural software. 
Table 1

Software Usage Reported by Agricultural Education Teachers

\begin{tabular}{|c|c|c|c|c|c|c|c|c|c|c|}
\hline & \multicolumn{2}{|c|}{ None } & \multicolumn{2}{|c|}{ Yearly } & \multicolumn{2}{|c|}{ Monthly } & \multicolumn{2}{|c|}{ Weekly } & \multicolumn{2}{|c|}{ Daily } \\
\hline & $\mathrm{N}$ & $\%$ & $\mathrm{~N}$ & $\%$ & $\mathrm{~N}$ & $\%$ & $\mathrm{~N}$ & $\%$ & $\mathrm{~N}$ & $\%$ \\
\hline Databases & 8.00 & 18.18 & 10.00 & 22.73 & 12.00 & 27.27 & 7.00 & 15.91 & 7.00 & 15.91 \\
\hline Word Processing & 0.00 & 0.00 & 1.00 & 2.27 & 1.00 & 2.27 & 11.00 & 25.00 & 31.00 & 70.45 \\
\hline Telecommunications & 4.00 & 9.09 & 2.00 & 4.55 & 6.00 & 13.64 & 9.00 & 20.45 & 23.00 & 52.27 \\
\hline Graphics & 4.00 & 9.09 & 10.00 & 22.73 & 16.00 & 36.36 & 12.00 & 27.27 & 2.00 & 4.55 \\
\hline Statistical Programs & 23.00 & 52.27 & 7.00 & 15.91 & 10.00 & 22.73 & 3.00 & 6.82 & 1.00 & 2.27 \\
\hline Programming & 27.00 & 61.36 & 6.00 & 13.64 & 9.00 & 20.45 & 2.00 & 4.55 & 0.00 & 0.00 \\
\hline Desktop Publishing & 12.00 & 27.27 & 10.00 & 22.73 & 11.00 & 25.00 & 8.00 & 18.18 & 3.00 & 6.82 \\
\hline Authoring Packages & 32.00 & 74.42 & 5.00 & 11.63 & 6.00 & 13.95 & 0.00 & 0.00 & 0.00 & 0.00 \\
\hline Test Generation/Scores & 10.00 & 22.73 & 1.00 & 2.27 & 8.00 & 18.18 & 19.00 & 43.18 & 6.00 & 13.64 \\
\hline Computer Assisted Instruction & 9.00 & 20.45 & 6.00 & 13.64 & 14.00 & 31.82 & 10.00 & 22.73 & 5.00 & 11.36 \\
\hline Grade Book & 11.00 & 25.00 & 1.00 & 2.27 & 2.00 & 4.55 & 6.00 & 13.64 & 24.00 & 54.55 \\
\hline Agriculture Software & 3.00 & 6.82 & 3.00 & 6.82 & 18.00 & 40.91 & 10.00 & 22.73 & 10.00 & 22.73 \\
\hline
\end{tabular}




\section{Application Uses of the Computer}

Respondents were asked to report the number of days they used the computer for various tasks related to teaching in an agricultural education classroom. Respondents reported an average of 94.5 days of the 200-day school year was used to develop lesson plans. The second most common use of computers was maintaining class lists with an average of 76.5 days per school year. Only five other uses averaged more than 50 days per school year. The development of handouts averaged 75.4 days, generation of tests averaged 64.4 days, worksheet generation averaged 61.6 days, grade reports averaged 57.1 days, and online research averaged 54.5 days of use per school year. All other items on the survey were used less than 40 days per school year. These items included; agricultural software in the instructional process (38.4 days), spreadsheets for student records (SAE visitation, addresses) (34.7 days), computer generated presentations (31.2 days), list serves (27.4 days), word finds (23.0 days), spreadsheets for student record books (21.5 days), sending e-mail to students (21.4 days), posters and banners (19.0 days), graphs and charts (18.2 days), crosswords (16.7 days), net presentation for the classroom (13.5 days), databases to create mailing lists (13.3 days), AgEd network (12.5 days), databases to created address lists (12.1 days), web page design (10.1 days), spreadsheets for business analysis ( 8.8 days), online shopping and purchases for instruction (7.8 days), and spreadsheets used for decision making (7.1 days). 
Table 2

Computer Use Applications

\begin{tabular}{|c|c|c|c|c|}
\hline & Min & Max & $\mathrm{M}$ & SD \\
\hline Overheads & 0 & 180 & 34.93 & 51.53 \\
\hline Computer generated presentations & 0 & 180 & 31.24 & 48.73 \\
\hline Graphs and charts & 0 & 120 & 18.28 & 31.23 \\
\hline Handouts & 0 & 200 & 75.35 & 62.42 \\
\hline Worksheets & 0 & 180 & 61.59 & 58.57 \\
\hline Tests-Quizzes & 4 & 200 & 64.43 & 51.54 \\
\hline Posters-Banners & 0 & 180 & 19.00 & 33.26 \\
\hline Lesson plans & 0 & 200 & 94.54 & 80.16 \\
\hline Word Finds & 0 & 180 & 23.04 & 45.01 \\
\hline Crosswords & 0 & 180 & 16.70 & 34.78 \\
\hline Class lists & 0 & 200 & 76.48 & 80.56 \\
\hline Grade reports & 0 & 200 & 57.13 & 74.14 \\
\hline Spreadsheets for student records (SAE visitations) & 0 & 180 & 34.74 & 54.48 \\
\hline Spreadsheets for student record books & 0 & 180 & 21.52 & 39.06 \\
\hline Spreadsheets for business analysis & 0 & 90 & 8.80 & 21.32 \\
\hline Spreadsheets for decision making & 0 & 80 & 7.07 & 16.06 \\
\hline Database to create inventories or sales & 0 & 120 & 12.70 & 23.77 \\
\hline Database to create address lists & 0 & 100 & 12.07 & 22.96 \\
\hline Database to create mailing lists & 0 & 180 & 13.33 & 32.20 \\
\hline Agricultural software in the instructional process & 0 & 180 & 38.41 & 57.25 \\
\hline
\end{tabular}


Table 2 (continued)

Computer Use Applications

\begin{tabular}{lcccc}
\hline & Min & Max & M & SD \\
\hline AgEd Network & 0 & 180 & 12.54 & 40.78 \\
Send e-mail to students & 0 & 200 & 21.48 & 51.24 \\
Listserves & 0 & 180 & 27.43 & 49.70 \\
Online research & 0 & 180 & 54.54 & 53.53 \\
Web page design & 0 & 200 & 10.07 & 31.79 \\
Online shopping and purchases for instruction & 0 & 80 & 7.85 & 19.94 \\
Net presentations for the classroom & 0 & 180 & 13.54 & 30.42 \\
\hline
\end{tabular}

Operating Systems

Respondents were asked to indicate the operating system(s) on their computers. They could provide more than one response due to having multiple computers. The most frequently occurring operating system was a version of Microsoft Windows ${ }^{\circledR}$. The most common version was Windows $95-98^{\circledR}$ with $89.1 \%$ of respondents $(n=41)$ reporting access to this operating system. This was followed by Windows $\mathrm{XP}^{\circledR}$ with $43.5 \%$ of respondents $(\mathrm{n}=20)$ reporting access to this operating system. Computers with Windows Millennium ${ }^{\circledR}$ were reported to have the least accessibility of the Windows systems with $28.3 \%(n=13)$. Apple or MAC computers were rare with only $2.2 \%$ of respondents $(n=2)$ reporting the operating system.

Disk Drives

Respondents were asked to indicate the type(s) of disk drives in the accessible computers. Of the 47 respondents, $95.6 \%$ of agricultural education programs indicated that they had $3 \frac{1}{2}$ 
inch disk drives and $97.8 \%$ of departments listed CD ROM drives. Respondents who reported CDROM drives and $3 \frac{1}{2}$ inch drives indicated that these drives existed in 76 to $100 \%$ of the computers accessible. Only $67.4 \%$ had CD writers, 50.0\% had CD DVD drives, and 30.4\% indicated having $5 \frac{1}{4}$ inch disk drives (see Table 1). These were most reported in $25 \%$ or less of the computers. Limited numbers of Zip $^{\circledR}$ drives either $100 \mathrm{MB}$ or $250 \mathrm{MB}$ were reported.

Respondents reported Zip ${ }^{\circledR}$ drives in $25 \%$ or less of available computers.

Table 3

Availability of Disk Drives

\begin{tabular}{|c|c|c|c|c|c|c|c|c|c|c|}
\hline & \multicolumn{2}{|c|}{$0 \%$} & \multicolumn{2}{|c|}{$25 \%$ or less } & \multicolumn{2}{|c|}{$26 \%-50 \%$} & \multicolumn{2}{|c|}{$51 \%-75 \%$} & \multicolumn{2}{|c|}{$76 \%-100 \%$} \\
\hline & $\mathrm{N}$ & $\%$ & $\mathrm{~N}$ & $\%$ & $\mathrm{~N}$ & $\%$ & $\mathrm{~N}$ & $\%$ & $\mathrm{~N}$ & $\%$ \\
\hline $51 / 4$ drive & 32 & 69.57 & 8 & 17.39 & 0 & 0.00 & 1 & 2.17 & 5 & 10.87 \\
\hline $31 / 2$ drive & 2 & 4.35 & 0 & 0.00 & 2 & 4.35 & 4 & 8.70 & 38 & 82.61 \\
\hline $250 \mathrm{MB}$ zip drive & 26 & 56.52 & 9 & 19.57 & 4 & 8.70 & 3 & 6.52 & 4 & 8.70 \\
\hline $100 \mathrm{MB}$ zip drive & 27 & 58.70 & 11 & 23.91 & 3 & 6.52 & 2 & 4.35 & 3 & 6.52 \\
\hline CD ROM & 1 & 2.17 & 2 & 4.35 & 2 & 4.35 & 9 & 19.57 & 32 & 69.57 \\
\hline CD Writer & 15 & 32.61 & 17 & 36.96 & 5 & 10.87 & 5 & 10.87 & 4 & 8.70 \\
\hline CD DVD & 23 & 50.00 & 14 & 30.43 & 3 & 6.52 & 3 & 6.52 & 3 & 6.52 \\
\hline
\end{tabular}

Number of Computers

Respondents were asked to indicate the number of accessible computers. Agricultural education departments reported an average of 5.21 computers per department. The departments however reported having access to an average of 39.07 computers for class use. Computer laboratories accounted for the additional access to computers. Sixteen respondents $(34.8 \%)$ reported access to a laptop computer with 13 of the 16 respondents $(28.3 \%)$ having access to 
only a single laptop. The maximum number of laptops that a department reported access to was three.

Table 4

Number of Computers in Each Department Use of Microcomputer Labs.

\begin{tabular}{|c|c|c|c|}
\hline & & $\mathrm{N}$ & $\%$ \\
\hline \multirow[t]{15}{*}{ Number of computers located in the department } & 0 & 2 & 4.3 \\
\hline & 1 & 5 & 10.9 \\
\hline & 2 & 10 & 21.7 \\
\hline & 3 & 6 & 13 \\
\hline & 4 & 7 & 15.2 \\
\hline & 5 & 3 & 6.5 \\
\hline & 6 & 2 & 4.3 \\
\hline & 7 & 2 & 4.3 \\
\hline & 8 & 1 & 2.2 \\
\hline & 9 & 1 & 2.2 \\
\hline & 13 & 1 & 2.2 \\
\hline & 14 & 1 & 2.2 \\
\hline & 15 & 2 & 4.3 \\
\hline & 18 & 3 & 6.5 \\
\hline & & 46 & 100 \\
\hline
\end{tabular}


Table 4 (continued)

Number of Computers in Each Department Use of Microcomputer Labs.

\begin{tabular}{llrr}
\hline & & \multicolumn{2}{c}{$\%$} \\
\hline Access to microcomputer lab & Yes & 44 & 95.65 \\
& No & 2 & 4.35 \\
\cline { 2 - 4 } Use lab for microcomputer instruction in ag classes & Yes & 46 & 100.00 \\
& & & \\
& No & 37 & 80.43 \\
& & 9 & 19.57 \\
\hline
\end{tabular}

\section{Computer Laboratories}

Agricultural education departments were asked to report the number of accessible computer laboratories and the amount of time they used the laboratories. Respondents reported access to an average of 2.33 computer laboratories per school. Nearly all departments $(n=44$, 95.7\%) reported access to at least one computer laboratory. Departments reported an average of 20.7 days per year in the computer laboratory. Of the departments reporting, $38(82.6 \%)$ were required to schedule time in the computer laboratories. Departments $(n=37,80.4 \%)$ used the laboratories for instruction in their agriculture classes. Nine departments (19.6\%) used the laboratories for uses other than agricultural or not at all.

\section{Printers}

Respondents were asked to report the number of various types of accessible printers. Ink printers were most common with an average of 3.42 printers per department. The average 
number of dot matrix printers was 2.27 per department. The average response was 2.00 laser printers per department

\section{Ink Printers}

Respondents were asked to indicate the number of ink printers they had in their department. Of the 46 respondents, 11 (23.9\%) reported having one ink printer and $10(21.7 \%)$ reported having two ink printers. Eight departments (17.4\%) reported no ink printers. Five agricultural education departments (10.9\%) reported access to four ink printers and four $(8.7 \%)$ departments had three ink printers. Five, six, seven, eight, 15, 18, and 32 ink printers were reported by one department $(2.2 \%)$ each.

\section{Dot Matrix Printers}

Respondents were asked to indicate the availability of dot matrix printers. Twenty-eight departments $(60.9 \%)$ reported no dot matrix printers. There were four departments $(8.7 \%)$ that reported access to one or two dot matrix printers. Two respondents $(4.3 \%)$ reported having five and two more reported eight dot matrix printers. Three, four, 12, 20, and 25 dot matrix printers were reported by one $(2.2 \%)$ department each.

\section{Laser Printers}

Respondents were asked to indicate the availability of laser printers. The most frequent response was none $(\mathrm{n}=14,30.4 \%)$. The second most frequent response for laser printers was one per department $(\mathrm{n}=13,28.3 \%)$. Nine departments $(19.6 \%)$ reported two laser printers. Four departments (8.7\%) reported three laser printers per department and nine laser printers were reported by two $(4.3 \%)$ departments. Five, 10 , and 14 laser printers were reported by one $(2.2 \%)$ department each. 
Scanners

Respondents were asked to indicate the number of accessible scanners. Agricultural education departments reported an average of 1.31 scanners per department. Eighteen departments (39.1\%) reported having one scanner and 16 departments (34.8\%) reported no scanners.

Table 5

Reported Availability of Hardware

\begin{tabular}{|c|c|c|c|c|c|c|c|c|}
\hline & \multicolumn{2}{|c|}{0} & \multicolumn{2}{|c|}{1} & \multicolumn{2}{|c|}{2} & \multicolumn{2}{|c|}{3} \\
\hline & $\mathrm{N}$ & $\%$ & $\mathrm{~N}$ & $\%$ & $\mathrm{~N}$ & $\%$ & $\mathrm{~N}$ & $\%$ \\
\hline Dot Matrix Printers & 28.0 & 62.2 & 4.0 & 8.9 & 4.0 & 8.9 & 9.0 & 20.0 \\
\hline Laser Printers & 14.0 & 31.1 & 13.0 & 28.9 & 9.0 & 20.0 & 9.0 & 20.0 \\
\hline Ink Printers & 8.0 & 17.8 & 11.0 & 24.4 & 10.0 & 22.2 & 16.0 & 35.6 \\
\hline Scanners & 16.0 & 35.6 & 18.0 & 40.0 & 6.0 & 13.3 & 5.0 & 11.1 \\
\hline LCD Projectors & 17.0 & 37.8 & 17.0 & 37.8 & 8.0 & 17.8 & 3.0 & 6.6 \\
\hline \multicolumn{9}{|c|}{ Media Converter (to use } \\
\hline TV as a Monitor) & 20.0 & 44.4 & 15.0 & 33.3 & 7.0 & 15.6 & 3.0 & 6.7 \\
\hline
\end{tabular}

Liquid Crystal Display (LCD) Projectors

Respondents were asked to report how many LCD projectors were in the department. Respondents reported an average of 1.00 projector per department. There was one department that reported five accessible projectors. Twenty-eight departments $(62.2 \%)$ reported having access to at least one LCD projector. Seventeen departments (37.0\%) reported no projector. 


\section{Media Converters (to use a TV as a monitor)}

Agricultural education departments were asked to indicate the number of accessible media converters. Twenty departments $(43.5 \%)$ reported no such devices. Fifteen departments (32.6\%) had one available device. Seven departments (15.2\%) reported two devices accessible and three, four, and five devices were reported by one department (2.2\%) each respectively. Internet Connection

Respondents were to indicate how or if they were connected to the Internet. Only two departments (4.35\%) reported they had no connection to the Internet. Two departments (4.35\%) reported a connection to the Internet by phone modem. The majority of the respondents, 42 departments (91.3\%), indicated a connection by means of a network system. 


\section{CHAPTER V}

\section{Conclusions}

\section{Statement of Problem}

This study was designed to determine what types of computer equipment exist in West Virginia's agricultural education programs, how the equipment is being utilized for the instructional program, and what factors limit the use of the equipment. The study results will provide information to state supervisors and teacher educators that might be useful in planning in-service strategies to maintain competencies of teachers in the use of computers.

\section{Objectives}

The specific objectives of this study were:

1. Identify the types of microcomputer hardware and software available and used by secondary agricultural education programs.

2. Identify problems associated with the use of microcomputers in the classroom.

3. Determine the types of microcomputers activities used by secondary agricultural education programs.

\section{Conclusions}

1. The use of DOS applications was limited. This suggests that agricultural education teachers are moving away from the operating system.

2. The most common uses of computers by agriculture educators were word processing, telecommunications, grade books, and test generation/scores.

3. Respondents showed little overall use of the computer in the development of overheads, computer generated presentations, graphs and charts, posters-banners, word finds, crosswords, class lists, and grade reports. 
4. The most frequent use of the computer was in the development of handouts, worksheets, tests, and quizzes for students.

5. Agricultural educators did not commonly use spreadsheets and databases.

6. The most frequent telecommunication use of computers was online research.

7. Approximately half of the agricultural education departments reported between two to four computers in the department. Two respondents reported having no computers in their departments.

8. Nearly all of the agriculture educators reported they have access to school computer labs. Most departments have to schedule time in the computer lab and the most common response was that the computer labs were being used five to ten days.

9. Operating systems varied a great deal but the most commonly used system was Windows ${ }^{\circledR}$ 95-98. Two departments reported the use of Mac or Apple computers.

10. Ink printers were the predominate type of printer.

11. The availability of LCD projectors and media converters (to use TV as a monitor) was reported in a majority of the departments.

12. Generally computers in agricultural education departments were equipped with $3 \frac{1}{2}$ inch floppy drives and CD ROMs. The use of 100 or 250MB zip drives and CD writers were limited.

13. Nearly all of the agricultural education departments were connected to the Internet via a network connection. Only two departments reported no connection to the Internet and two reported using phone modem connections. 


\section{Implications}

Based on study results, the study has the potential to have implications on computer inservices activities for agriculture education. Possible in-service topics should include listserves, databases, and spreadsheets.

The study has the potential to have implications on hardware and software purchases. Study results can be used to identify deficient areas in hardware, software, and uses.

\section{Recommendations}

1. It is recommended that additional research be conducted to determine why the use of programs other than word processing, telecommunications, grade books, and test generation/scores were limited.

2. Additional research should be conducted to determine the limiting factors associated with the use of computers in the curriculum.

3. Additional in-service on spreadsheets and databases should be provided for agricultural educators.

4. Research should be conducted on the factors that limit computer lab use to five or ten days yearly.

5. In-service workshops should be limited to Windows ${ }^{\circledR}$ operating systems software.

6. Additional research should be conducted on how LCD projectors and TV converters are being used in the classroom. 


\section{REFERENCES}

Andelt, L., Barrett, L. A., \& Bosshamer, B.K. (1997, December). Employer assessment of the skill preparation of students from the college of agricultural sciences and natural resources University of Nebraska-Lincoln: Implications for teaching and curriculum. NACTA Journal, 41(4), 47-53.

Birkenholtz, R. J., Stewart, B. R., McCaskey, M. J., Ogle, T. D., \& Linhardt, R. E. (1989). Using microcomputers in education: assessment of three teaching strategies. Journal of the American Association of Teacher Educators in Agriculture, 30(1), 51-59.

Bowen, B. E., Mincemoyer, D. L., \& Parmley, J. D. (1983). Use of computer technology by teacher education in agriculture programs: student experiences and programmatic applications. Journal of the American Association of Teacher Educators in Agriculture, 24(3), 14-21.

Camp, W. G., \& Sutphin, H. D. (1991) Integrating microcomputers and related technologies in agricultural education. Journal of the American Association of Teacher Educators in Agriculture, 32(1) 41-46.

Davis, P. (1997, September). What computer skills do employers expect from recent college graduates? T.H.E. Journal, 25(2), 74-79.

Early, R. S. (2002). The integration of instructional technology into public education: promises and challenges. Educational Technology, 42(1), 5-13.

Hill, J., \& Hannafin, M. J. (2001). Teaching and learning in digital environments: The resurgence of resource-based learning. Education Technology Research and Development, $49(3)$ 37-52. 
Johnson, D. M., Ferguson, J. A., \& Lester, M. L., (2002). Computer experiences, self-efficancy and knowledge of students entering a college of agriculture. NACTA Journal, 46(1), 5867.

Miller, C., \& Kotrlik, J. W. (1987). Microcomputer use in vocational agriculture programs in the United States. Journal of the American Association of Teacher Educators in Agriculture, 28(1), 34-40, 49.

Miller, L. E., \& Smith, K. (1983). Handling nonresponse issues. Journal of Extension. 24, 45-50

Miller, W. W., \& Foster, R. M. (1985). An assessment of microcomputer competencies needed by vocational agriculture instructors in Nebraska and Iowa. Journal of the American Association of Teacher Educators in Agriculture, 26(1), 30-38.

Odell, K. S. (1994). Microcomputer utilization in West Virginia secondary school agriculture programs. In D. G. Watson, F. S. Zazeuta, \&T. V. Harrison, (eds.). Computers in agriculture. St. Joseph, MI: American Society of Agricultural Engineers.

Patten, M. L., (2000). Introduction to research methods. S. Young, B. Koplin, E. Fuess, C. Alcorn, \& R. R. Bruce (Eds.), Understanding research methods (2 ${ }^{\text {nd }}$ ed.). (pp.9-10). Los Angeles, CA: Pyrczak.

Raven, M. R., \& Welton, R. F. (1988). An assessment of microcomputer utilization in Kansas vocational agriculture programs. Journal of the American Association of Teacher Educators in Agriculture, 30(1) 23-31.

Rohrbach, N. F., \& Stewart, B. R. (1986). Using microcomputers in teaching. Journal of the American Association of Teacher Educators in Agriculture, 27(4), 18-25. 
U.S. Department of Education, National Center for Educational Statistics. (2000, September) Teacher's tools for the 21 $1^{\text {st }}$ century: A report on teachers' use of technology, NCES 2000-102 Washington DC: Author.

Zidon, M.G., \& Luft, V.D. (1986). Assessment of the use of microcomputers in North Dakota secondary vocational agriculture departments. Journal of the American Association of Teachers Educators in Agriculture, 28(1): 9-16. 


\section{APPENDICES}


APPENDIX A:

Survey Instrument 


\section{Computer}

\section{Applications}

\section{in Your}

Agricultural

\section{Education Program}

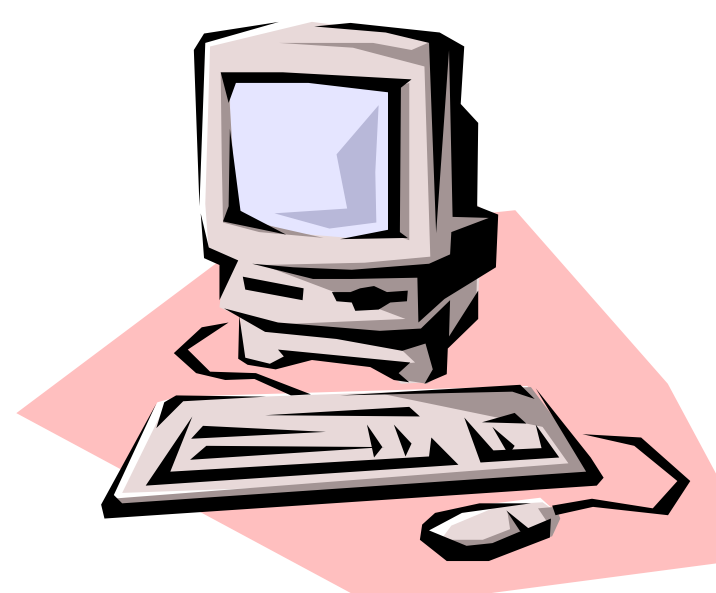

West Virginia University

Agricultural and Environmental Education P.O. Box 6108

Morgantown, WV 26506 
Thank you for choosing to complete this questionnaire. Please read and follow the instructions on each section carefully.

When you are finished, feel free to write additional comments on the back of the survey and then place the questionnaire in the return envelope and send to my address.

Please turn the page.
Answer the following questions by circling the response indicating the amount of time you use the following types of applications. Use the following scale for your answers.

\begin{tabular}{|c|c|}
\hline 1. & Overheads \\
\hline 2. & Computer generated presentations \\
\hline 3. & Graphs and charts \\
\hline 4. & Handouts \\
\hline 5. & Worksheets \\
\hline 6. & Tests/Quizzes \\
\hline 7. & Posters/Banners \\
\hline 8. & Lesson plans \\
\hline 9. & Word Finds \\
\hline 10. & Crosswords \\
\hline 11. & Class lists \\
\hline 12. & Grade reports \\
\hline 13. & $\begin{array}{l}\text { Spreadsheets for student records (SAE } \\
\text { visitations, Addresses) }\end{array}$ \\
\hline 14. & Spreadsheets for student record books \\
\hline 15. & Spreadsheets for business analysis \\
\hline 16. & Spreadsheet for decision making \\
\hline 17. & Database to create inventories or sales \\
\hline 18. & Database to create address lists \\
\hline 19. & Database to create mailing lists \\
\hline 20. & $\begin{array}{l}\text { Agricultural software in the instructional } \\
\text { process }\end{array}$ \\
\hline 21. & AgEd Network \\
\hline 22. & E-mail students \\
\hline
\end{tabular}


Answer the following questions by indicating the best estimate of the approximate number of days that your department uses the following applications in conjunction with a computer.

\begin{tabular}{|c|c|c|c|c|c|}
\hline & $\begin{array}{l}\mathscr{O} \\
\text { Z }\end{array}$ & 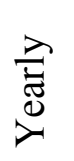 & 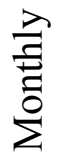 & $\begin{array}{l}\frac{\lambda}{2} \\
\frac{\pi}{0} \\
\frac{D}{3}\end{array}$ & $\frac{\lambda}{\bar{\pi}}$ \\
\hline 1. Disk Operating System DOS & 1 & 2 & 3 & 4 & 5 \\
\hline 2. $\quad$ Spreadsheets & 1 & 2 & 3 & 4 & 5 \\
\hline 3. Databases & 1 & 2 & 3 & 4 & 5 \\
\hline 4. Word Processing & 1 & 2 & 3 & 4 & 5 \\
\hline 5. Telecommunications & 1 & 2 & 3 & 4 & 5 \\
\hline 6. Graphics & 1 & 2 & 3 & 4 & 5 \\
\hline 7. $\quad$ Statistical Programs & 1 & 2 & 3 & 4 & 5 \\
\hline 8. $\quad$ Programming & 1 & 2 & 3 & 4 & 5 \\
\hline 9. Desktop Publishing & 1 & 2 & 3 & 4 & 5 \\
\hline 10. Authoring Packages & 1 & 2 & 3 & 4 & 5 \\
\hline 11. Test Generation/Scores & 1 & 2 & 3 & 4 & 5 \\
\hline $\begin{array}{l}\text { 12. Computer Assisted } \\
\text { Instruction }\end{array}$ & 1 & 2 & 3 & 4 & 5 \\
\hline 13. Grade Books & 1 & 2 & 3 & 4 & 5 \\
\hline 14. Agriculture Software & 1 & 2 & 3 & 4 & 5 \\
\hline
\end{tabular}

\begin{tabular}{|l|l|l}
\hline 23. & Listserves & \\
\hline 24. & Online research & \\
\hline 25. & Web page design & \\
\hline 26. & $\begin{array}{l}\text { Online shopping and purchases for } \\
\text { instruction }\end{array}$ & \\
\hline 27. & Net presentations for the classroom & \\
\hline
\end{tabular}

Fill in the blank with the best approximate answer

1. Number of functional computers located in the department

2. Number of accessible computers with Window XP

3. Number of accessible computers with Windows Millennium

4. Number of accessible computers with Windows 95/98

5. Number of accessible MAC/Apple computers

6. Number of accessible computers with other operating system

7. Number of laptops in the department

8. Access to a school microcomputer lab? Yes / No

9. Number of school microcomputer labs

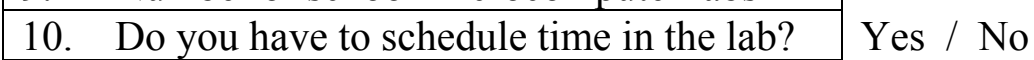

11. Use lab for microcomputer instruction in Ag classes?

Yes / No

12. Approximate days of class in lab

13. Number of accessible PC compatible computers

14. Number of dot matrix printers 


\begin{tabular}{|cl|}
\hline 15. & Number of laser printers \\
\hline 16. & Number of ink printers \\
\hline 17. & Number of scanners \\
\hline 18. & LCD projectors \\
\hline 19. & Media converter (to use TV as a monitor) \\
\hline
\end{tabular}

Answer the following questions as to the approximate availability of the devices on the accessible computers:

\begin{tabular}{|c|c|c|c|c|}
\hline 1. & 2. & 3. & 4. & 5. \\
$0 \%$ & $25 \%$ or less & $26 \%$ to $50 \%$ & $51 \%$ to $75 \%$ & $76 \%$ to $100 \%$ \\
\hline
\end{tabular}

Please respond to the following question:

What are the five greatest limitations/obstacles to using the microcomputer as an educational tool in your agriculture program?

1.

2.

3.

4.

\begin{tabular}{|c|c|c|c|c|c|}
\hline & $\dot{o}^{\circ}$ & $\begin{array}{l}\text { Dे } \\
\frac{0}{0} \\
\dot{0} \\
\stackrel{0}{0} \\
\text { ปे }\end{array}$ & $\begin{array}{l}\stackrel{0}{0} \\
\text { in } \\
0 \\
\stackrel{ \pm}{0} \\
\stackrel{0}{0} \\
\stackrel{0}{0}\end{array}$ & $\begin{array}{l}\stackrel{0}{i} \\
\stackrel{1}{\circ} \\
\stackrel{8}{0} \\
\stackrel{0}{0} \\
\text { in }\end{array}$ & $\begin{array}{l}\stackrel{8}{0}_{8}^{\circ} \\
\frac{0}{0} \\
\stackrel{0}{0} \\
\stackrel{0}{0}\end{array}$ \\
\hline 18. $5 \frac{1}{4} 4$ drive & 1 & 2 & 3 & 4 & 5 \\
\hline 19. $3 \frac{1}{2}$ drive & 1 & 2 & 3 & 4 & 5 \\
\hline 20. $250 \mathrm{MB}$ zip drive & 1 & 2 & 3 & 4 & 5 \\
\hline 21. $100 \mathrm{MB}$ zip drive & 1 & 2 & 3 & 4 & 5 \\
\hline 22. $\mathrm{CD} \mathrm{ROM}$ & 1 & 2 & 3 & 4 & 5 \\
\hline 23. CD Writer & 1 & 2 & 3 & 4 & 5 \\
\hline 24. CD DVD & 1 & 2 & 3 & 4 & 5 \\
\hline $\begin{array}{l}\text { 25. How are you connected to the } \\
\text { internet? }\end{array}$ & \multicolumn{5}{|c|}{$\begin{array}{l}\text { I'm not } \\
\text { Phone modem } \\
\text { Network }\end{array}$} \\
\hline
\end{tabular}


APPEMDIX B:

Letter to Participating WV Agriculture Teachers 
July 5,2002

\section{MEMORANDUM}

To: $\quad$ West Virginia Agriculture Teachers

From: $\quad$ David Aberegg

Graduate Student

Layle D. Lawrence

Graduate Advisor

Throughout my time as an undergraduate in the field of Agricultural and Environmental Education, I have been asked to complete various tasks using a microcomputer. The microcomputer tasks included assignments for the college as well as other departments across the University. The inclusion of microcomputer technology into the undergraduate curriculum leads me to the topic for my Master's thesis. My research will focus on the kinds of microcomputer equipment and software secondary agricultural education teachers have access to in their programs and how it is being used to enhance the education of their students.

Considering the rapid change in computers and the related technologies, there is a need to research the current state of microcomputer use in the secondary agriculture education classroom as it relates to the types of hardware and software available as well as applications computers are used for within the classroom. The results of this study will be used to prepare a thesis in partial fulfillment for the requirements for a Master of Science degree in Agricultural and Environmental Education. In addition, the results will have an influence on determining the types of in-service needed by agricultural education teachers in West Virginia.

The enclosed questionnaire will only take a few minutes of your time and participation in this research study is voluntary. If you are part of a multi-teacher department, please complete the program as a department rather than as individual teachers. You may skip any question that you do not feel comfortable answering. Please be assured that all information will be held as confidential as is legally possible. Survey results will be reported in a summary format and individual responses will not be identifiable. A code number at the bottom of the survey will be used for identification of non-respondents for follow-up and will be destroyed before the data are analyzed.

Please return your questionnaire by July 20, 2002 in the postage paid self-addressed return envelope. Your prompt attention to this questionnaire will be appreciated. 
APPENDIX C:

Follow Up Letter 
July 30, 2002

\section{MEMORANDUM}

To: $\quad$ West Virginia Agriculture Teachers

From: $\quad$ David Aberegg

Graduate Student

Layle D. Lawrence

Graduate Advisor

Throughout my time as an undergraduate in the field of Agricultural and Environmental Education, I have been asked to complete various tasks using a microcomputer. The microcomputer tasks included assignments for the college as well as other departments across the University. The inclusion of microcomputer technology into the undergraduate curriculum leads me to the topic for my Master's thesis. My research will focus on the kinds of microcomputer equipment and software secondary agricultural education teachers have access to in their programs and how it is being used to enhance the education of their students.

Considering the rapid change in computers and the related technologies, there is a need to research the current state of microcomputer use in the secondary agriculture education classroom as it relates to the types of hardware and software available as well as applications computers are used for within the classroom. The results of this study will be used to prepare a thesis in partial fulfillment for the requirements for a Master of Science degree in Agricultural and Environmental Education. In addition, the results will have an influence on determining the types of in-service needed by agricultural education teachers in West Virginia.

The enclosed questionnaire will only take a few minutes of your time and participation in this research study is voluntary. If you are part of a multi-teacher department, please complete the program as a department rather than as individual teachers. You may skip any question that you do not feel comfortable answering. Please be assured that all information will be held as confidential as is legally possible. Survey results will be reported in a summary format and individual responses will not be identifiable. A code number at the bottom of the survey will be used for identification of non-respondents for follow-up and will be destroyed before the data are analyzed.

Please return your questionnaire by August 15, 2002 in the postage paid self-addressed return envelope. Your prompt attention to this questionnaire will be appreciated. 
VITA 


\section{David T. Aberegg}

Residence Info

58 Debbie Terrace

Berkeley Springs, WV 25411

daberegg@access.k12.wv.us
Permanent Address

254 Lang Dr.

New Martinsville, WV 26155

daberegg@hotmail.com

OBJECTIVE: $\quad$ To be employed as a teaching professional

EDUCATION: $\quad$ WEST VIRGINIA UNIVERSITY Morgantown WV, 1996-1998. Received a BS degree in Agriculture with a major in Agricultural and Environmental Education. Course work specializing in: ag mechanics, production agriculture, leadership, computers, adult education, and teaching methods.

PROFESSIONAL Current GPA 3.60/4.00 scale. EXPERIENCE:

Student Teacher West Virginia University/ Hundred High School, Responsibilities included Preparation and teaching of various classes Supervision of students Preparation of extra curricular events.

\section{Teaching Assistant West Virginia University}

Teacher Berkeley Springs High School Taught Agriculture Education Grades 9-12 from 7/1/03 - Current. Content areas in Hydroponics, Ag Mechanics, Ag and Natural Resources, Animal Production, Horticulture, and Aquiculture.

Teacher West Virginia Northern Community College Taught Computer competencies in Microsoft Excel.

Substitute Teacher Wetzel Co., Preformed basic substitute duties accepting jobs at various schools in the County 2001-2002 school year

Lecturer West Virginia University, AgEd 101 Computers in Agriculture 2001-2002 Spring Taught one section of class Responsibilities included creating lesson plans lecturing working with students in lab and the supervision of two teaching assistants.

AgEd 461 Composting and Waste Management 2001-2002 Fall Responsibilities included lectured class prepared tests weekly assignments and grades. 
AgEd 262 Agriculture communications 2000-2001 Fall and Spring Graded all material, Preparation of all audiovisual and computer equipment, Instruction of various topics, assistance in the preparation of student communication projects

AgEd 62 Computers in Agriculture 1999-2000 Fall Assisted with grading and instruction of students in computer application

EXPERIENCE: Proprietor, Aberegg Mowing Service, New Martinsville, WV

Responsibilities included: Mowing, trimming, edging, fertilization, landscaping, and watering lawns and yards. 1992- 1999.

Laborer/Mechanic, A-1 Rent-All. New Martinsville, WV 26155. Responsibilities included: repaired small engines, and rental equipment.

Laborer/Office work, MJD Inc. Proctor, WV Responsibilities included: Grounds maintenance for various facilities, Repair work to machinery, Loading and unloading of supplies, preparing bills and customer service.

Forman, Ormet Primary Aluminum Plant Hannibal, OH Responsibilities included;_Supervision and quality control of fires and products produced in furnace room. 